\title{
Developing Aedes Albopictus as a Vector With Sterile Insect Technique (SIT) to Control Dengue in Semarang City
}

\author{
Martini Martini ${ }^{1,}{ }^{*}$, Dirga Maulida ${ }^{1}$, Ali Rahayu $^{2}$, Nissa Kusariana ${ }^{1}$, Retno Hestiningsih ${ }^{1}$, and Sri Yuliawati $^{2}$ \\ ${ }^{1}$ Faculty of Public Health, Diponegoro University, Semarang - Indonesia \\ ${ }^{2}$ Laboratory of Isotop and Radiation Application Center (IRAC), BATAN, South Jakarta - Indonesia
}

\begin{abstract}
Dengue is still being a health problem in Semarang City. Aedes albopictus is a secondary vector but they could be a main vector in an urban area. Sterile Insect technique (SIT) is an alternative tool to control dengue that is more safety than using pesticide. The objective of this study was to develop Aedes albopictus with SIT method to control dengue in Semarang City. Male pupae were irradiated at the doses of 0 (control), 60, 70, and $80 \mathrm{~Gy}$, using 3 replications. The parameters that were measured to determine the quality of males that have been sterilized are number of eggs, sterility level and mating competitiveness. The level of sterility was determined by the percentage of unhatched eggs. Mating competitiveness was determined by Fried index with a ratio of $30: 10: 10$ (radiated males : fertile males : virgin females). There was no significant difference $(\mathrm{p} \leq 0.05)$ at sterility level to the irradiated males. The results indicated that decreasing irradiated doses conducted increasing in mating competitiveness. However, further trial in field conditions should be undertaken to estimate the release ratio of irradiated males to produce an effect on wild populations.
\end{abstract}

Keywords: Sterile Insect Technique; sterility; mating competitiveness; Fried index; Aedes albopictus

\section{Introduction}

Aedes albopictus is also a vector of DHF. Even though it is not as important as Aedes aegypty. In laboratory, those two mosquito species could spread dengue virus through the female mosquito to the eggs and its generations, while Aedes albopictus is faster in spreading. Aedes albopictus basically is a forest species that is adapted to the human environment in the rural, suburban and urban areas [1].

An appropriate vector control method is needed. Some vector control methods that can be used including the use of chemical compound, biological, mechanical, and environmental management and by using radiation (Sterile Insect Technique) [2]. The use of insecticide has some weaknesses including the population that is immune to insecticide, the environmental contamination and kill the organism which is not the target [3].

The success rate of the SIT application in vector control can be seen from the amount of the population decrease after the application. One of the parameters is the decreasing of egg fertility percentage. The fertile egg is an egg that contains embryo and could be hatched. Meanwhile, the sterile egg is an egg that has no embrio and could not hatch. The sterile egg as the product of SIT application is an egg from the insemination of sterile sperm with the embrio of normal female [4].

The control of mosquito population using the SIT approach does not always succeed and not always fail. One of the causes of SIT failure in controlling mosquito populations is the sterile male which is released has a poor quality if it is competing with the natural male in the release area [5]. Research about the most appropriate level of sterile dose to sterilize the mosquito and acquiring the value of high competitiveness was previously conducted to several species including Anopheles sp. [6], Anopheles coluzzi. [7], Aedes aegypty [5,8], and Aedes albopictus [16] mosquitoes. This research was basically similar to the one conducted by Bellini to Aedes albopictus mosquito, but different strain of mosquito was used.

The radiation dose has a big influence to affect the success rate of vector control using SIT approach. A good radiation dose that is acknowledged to radiate Aedes $s p$. mosquito is $60-80 \mathrm{~Gy}$. So this research aimed to know the appropriate dose to obtain the higher value of egg sterility with a value of mating competitiveness that is considered good.

\section{Methodology}

\subsection{Study Design and Sampling Procedure}

This research was conducted in the Laboratory of mosquito cultivation, Isotop and Radiation Application Center (IRAC), BATAN, South Jakarta, by using pupaa and imago of 2nd to 10th generation of Aedes albopictus mosquito (F2-F10) which were coming from the field collection in BATAN Pasar Jum'at area. The mosquitoes

*Corresponding author: tinihen65@yahoo.co.id 
that were used were cultivated in the Pest Control Laboratory IRAC, BATAN, South Jakarta. The larva was cultivated in a tray with $\mathrm{p} \times 1 \times \mathrm{t}=30 \times 20 \times 10 \mathrm{~cm}$ filled with water in depth of $\pm 5 \mathrm{~cm}$. the larva was feed

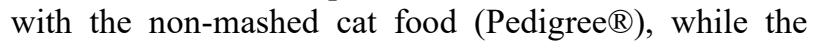
mature mosquitoes were cultivated in a place size $100 \mathrm{x}$ $40 \times 40 \mathrm{~cm}$. the room condition is kept to be constant at $25-280 \mathrm{C}$ temperature and the humidity of $80 \%$. The lighting in the mature cultivation room was adjusted to L12:D12. The sugar liquid 10\% which was dropped in cotton was given continually as the food for the mature mosquitoes the pupa that was used in this research were the pupa with ages of 24 hours. Those pupa were obtained from the larva colony that was cleaned from the old pupa $(\approx 36-48$ jam $)$, exactly 24 hours before the irradiation time.

\subsection{Instrument Development and Data Collection Procedure}

Irradiation was conducted by using Irradiator Gamma Chamber 2.0, IRAC, BATAN using Cobalt-60 as the radiator source. The pupa was radiated in a vial glass volume $231 \mathrm{ml}$. This research was conducted by radiating pupa in three doses; 60,70,80 Gy and the control was included as the comparison. Ten male and female mosquitoes were used in every mating combination in three times of repetition. There were three mating combinations that were done. First, 10 sterile males: 10 normal females. Second, 10 sterile males : 10 normal males : 10 normal females. Third, 30 sterile males: 10 normal males: 10 normal females. A comparison as included, 10 normal males: 10 normal females.

In this research the number of eggs produced after the radiation was counted, the percentage of egg sterility and the value of mating competitiveness measured by using Fried index formula.

\subsection{Data Processing and Analysis}

Data analysis was done by ANOVA test to know differences among intervention of dose with $\alpha=0.05$. Data entry and analysis used computerize.

\section{Results}

Table 1 Result of Variance Test of the Average Number and Sterility of Aedes albopictus eggs

Table 1. Result of Variance Test of the Average Number and Sterility of Aedes albopictus eggs

\begin{tabular}{|c|c|c|c|}
\hline Dose & \multicolumn{2}{|c|}{ Average eggs number \pm SD } & $\begin{array}{c}\text { Sterilityy (\%) } \\
\pm \mathrm{SD}\end{array}$ \\
\hline 0 & 487 & $\pm 95^{\mathrm{ab}}$ & $21.06 \pm 7.46^{\mathrm{a}}$ \\
\hline 60 & 588 & $\pm 39^{\mathrm{a}}$ & $99.93 \pm 0.11^{\mathrm{b}}$ \\
\hline
\end{tabular}

\begin{tabular}{|c|c|c|c|}
\hline 70 & 513 & $\pm 87^{\mathrm{ab}}$ & $99.93 \pm 0.11^{\mathrm{b}}$ \\
\hline 80 & 309 & $\pm 79^{\mathrm{b}}$ & $99.33 \pm 0.61^{\mathrm{b}}$ \\
\hline
\end{tabular}

Note:

1. Dose 0: Not radiated (as the control)

2. The different letter showed the significant difference at $\alpha=0,05$

Table 1 showed that in mating combination of 10 sterile males : 10 normal females, the higher the radiation dose, the fewer the number of eggs produced. However, the significant difference only happen between dose 60 Gy and $80 \mathrm{~Gy}$. The percentage of sterility for control was 21.06 which showed $88.96 \%$ eggs had hatched. Meanwhile in the radiation dose of 60,70 and $80 \mathrm{~Gy}$ showed that sterility number was not different, in $99 \%$. The sterility value to increase along with the increasing doses.

Table 2. The Value of Mating Competitiveness Aedes albopictus mosquitoes in mating combination of $30 \widehat{\partial}$ Radiation: 10 ๙ Normal : 10 ㅇ Normal

\begin{tabular}{|c|c|c|}
\hline Dose & $\begin{array}{c}\text { Sterilityy } \\
(\%)\end{array}$ & C index \\
\hline 60 & 99 & 0.28 \\
\hline 70 & 99 & 0.12 \\
\hline 80 & 99 & 0.10 \\
\hline
\end{tabular}

The value of mating competitiveness ( $\mathrm{C}$ index) of Aedes albopictus mosquitoes for the dose of $60 \mathrm{~Gy}$ and $80 \mathrm{~Gy}$ were $0.28,0.12$ and 0.10 . The highest value of competitiveness in this research was produced by the dose of 60 Gy at 0.28 , while the lowest was produced by the dose of $80 \mathrm{~Gy}$ at 010 . Based on the result of Pearson Correlation test, $\mathrm{R}$ square value or Determination Coefficient (DC) was $83.2 \%$ which can be interpreted that the free variable Dose had a contribution effect for $83.2 \%$ to the variable Mating Competitiveness ( $\mathrm{C}$ index) and the other 16.8 was affected by another factor outside of the Dose variable. A regression equation was obtained $[y=0.797-0.009(x)]$, with $y$ constant is the value of mating competitiveness and $\mathrm{x}$ constant is the radiation dose. The significant value showed the result of 0.269 which was $<$ than the significant criteria (0.05), therefore, the model of regression equation based on the research data was not significant.

\section{Discussion}

The number of eggs produced by females in the mating combination of 10 males : 10 females in dose 0 Gy (control), 60 Gy, 70 Gy and 80 Gy in order were 487,588 and 309 eggs. That result showed that there was no significant difference to the control $(p \leq 0,05)$ in each dose, except if the number of eggs in dose of 60 Gy 
compared to the dose of $80 \mathrm{~Gy}$. It showed that insemination remained to occur. However, the embryo that was formed could not survive because there was dominant lethal mutation brought by the sperm of male mosquitoes. The dominant lethal mutation can be seen from the increasing of sterility level along with the increasing of gamma radiation dose that was given [9]. The difference of number of eggs produced by the female mosquitoes according to Hamady is relevant with the size of mosquitoes body. Usually, the small females produce fewer eggs and the eggs growth is relatively slow, while the females in which body are bigger produce more eggs in one of its life cycles [10]. In this research was also conducted an observation on the females body size. The taking of females was done randomely through the square jar bugdoom which was sterilized from the males.

Sterility is one of the parameters on population decreasing. A sterile egg showed that the radiation process to the male pupa has an effect. A sterile egg is an egg which does not contain embryo. The increase of sterility egg is caused by the mating between sterile male and normal female so a sterile generation was produced. The average level of sterility in three times repetition in this research as shown in Table 1 in mating of female and male radiation dose 60 Gy, 70 Gy and 80 Gy with the ratio of $1: 1$ was that the three of them obtained the same value reaching $99 \%$. This result was almost in accordance with the research conducted by Zhang et al, which obtained sterility value of Aedes albopictus mosquito in laboratory and field were $99.5 \%$ ad $99.8 \%$ in order, but in the lower dose combined with Incompatible Insect Technique (IIT) [11].

According to Helinski et al, the sterile dose on Anopheles mosquitoes could be reached in dose of 100$120 \mathrm{~Gy}$, but only produce the sterility level above $98 \%$, means that the sterile dose was not the standard dose, sterile dose could change affected by many factors, one of them is the sexual maturity of mosquito. The higher the dose distribution could damage the somatic cells which could affect in the decreasing of physical ability to mate. Usually, the failure of mating is caused by the damage on genitalia organ as the radiation effect. The high radiation dose ( $>120 \mathrm{~Gy})$ needed to make the male sterile can also cause the failure of male mosquitoes to move the sperm to the female mosquitoes [8].

The higher dose would cause a negative effect on the mating competitiveness.6 For instance, in An. Stephensi [5], the males from radiated pupa in dose of $80 \mathrm{~Gy}$ had a mating competitiveness 1.7 times bigger than the males from radiated pupa at $120 \mathrm{~Gy}$ dose. That pattern also happened to An. Arabiensis [12] and Culex quinquefasciatus [5]. The value of mating competitiveness or $\mathrm{C}$ index is useful to determine the number of sterile male mosquitoes which will be spread. For example, if the sterile male mosquitoes are known to have mating competitiveness for 0.333 , so the number of sterile males to be spread should be three times of the natural population to increase the possibility of mating between sterile males and natural females [7].

There were many researches which showed the decreasing in mating competitiveness because of radiation. Mostly those researches were explained that it was affected by the decreasing of life endurance, mating ability or the sperm supply. Moreover, the radiation process caused the decrease of flying ability, the ability to detect female and to move the sperm from males to females [7]. The ability of mosquitoes to do the mating with females according to Zhang et al., was more depending on the factors such as the flying ability and the participation in mating behavior which is compatible [11].

From the result that was obtained, so the most effective dose to be used as the SIT application in Aedes albopictus was by using dose of 60 Gy with the level of sterility reaching $99 \%$ and the value of mating competitiveness was 0.28 . The low value of mating competitiveness could be affected by the decreasing of the age of sterile male mosquitoes so it reduced the contact time with the females.

\section{Conclusion}

The higher the dose, the number of eggs produced by Aedes albopictus will decrease. The increasing of radiation dose is also affecting the increase of sterility form Aedes albopictus mosquitoes. Whereas the decreasing of radiation dose will affect the increase of mating competitiveness value. The mating competitiveness value that was obtained in this research was from dose of 60 Gy with the value of mating competitiveness at 0.28 and the sterility level at $99 \%$.

The application of SIT as the vector control especially for Aedes albopictus mosquito should be tried, considering the result in this research was good enough. However, the radiation dose that was used in this research was relatively high, proven by the obtaining of sterility number which was not too much different and only based on the laboratory, so this research could be developed again by using the lower dose and conducted with semi-field procedure.

Thank Undip Rector, who facilitate the funding through PNBP funding, so this research could be conducted. The head of BATAN for facilitating the laboratory to produce the sterile insects.

\section{References}

1. DF. Rahayu, A. Ustiawan. Identifikasi Aedes Aegypti Dan Aedes. Balaba. 9, 1 (2013)

2. H. Simanjuntak. Efektivitas Akar Tanaman Tuba (Derriselliptica) untuk Pengendalian Nyamuk Pengendalian Nyamuk Anopheles sp. (2005)

3. LP. Ambarita. Pengendalian Nyamuk Vektor Menggunakan Teknik Serangga Mandul (TSM) Vector Control using Sterile Insect Technique (SIT). 111-118 (2015)

4. R. Setiyaningsih, M. Agustini, A. Rahayu. Pengaruh Pelepasan Nyamuk Jantan Mandul terhadap Fertilitas dan Perubahan Morfologi Telur Aedes aegypti. Vektora. 7, 2: 71-78 (2015) 
5. HI. Sasmita, B. Ernawan. Kualitas Nyamuk Jantan Mandul Aedes aegypti L. Hasil Iradiasi Gamma: EfekIradiasi Pada Fase Pupa dan Dewasa. J AplIsot Radiasi. 10, 2:149-158 (2014).

6. M. Helinski, AG. Parker, B. Knols. Radiation biology of mosquitoes. 13:1-13 (2009)

7. H. Maïga, D. Damiens, A. Niang, S. Sawadogo, O. Fatherhaman, RS. Less, et al. Mating competitiveness of sterile male Anophelescoluzzii in large cages. 1-6 (2014).

8. S. Nurhayati, B. Santoso, A. Rahayu, D. Tetriana. Pengaruh Radiasi Dinar Gamma terhadap Daya Saing Kawin Nyamuk Aedes aegypti sebagai Vektor Demam Berdarah Dengue (DBD) (2009)

9. S. Nurhayati, B. Yunianto, T. Ramadhani, B. Ikawati, B. Santoso, A. Rahayu. Controlling Aedes aegypti Population as DHF Vector With Radiation Based Sterile Insect Technique in Banjarnegara Regency, Central Java. J Sains dan TeknolNuklIndones. 14, 1:1-10 (2013)

10. D. Hamady, NB. Ruslan, AH. Ahmad, CSM. Rawi, H. Ahmad, T. Satho, et al. Colonized Aedesalbopictus and its sexual performance in the wild: implications for SIT technology and containment, 1-9 (2013)

11. D. Zhang, RS. Lees, Z. Xi, K. Bourtzis, JRL. Gilles. Combining the sterile insect technique with the incompatible insect technique: III-robust mating competitiveness of irradiated triple wolbachiainfected Aedesalbopictus males under semi-field conditions. PLoS One. 11, 3:1-15 (2016)

12. MEH. Helinski. Reproductive Biology and Induced Sterility as Determinants for Genetic Control of Mosquitoes with the Sterile Insect Technique, 203 (2008) 